\title{
Společné vzdělávání pohledem ředitelů škol a školských zařízení zapojených do projektu APIV B
}

\author{
Irena Balaban \\ Cakirpaloglu, ${ }^{\mathrm{a}}$ \\ Jana Odstrčilová, ${ }^{\mathrm{b}}$ \\ Ivana Musilová, ${ }^{\mathrm{c}}$ \\ Zonna Bařinkovád
}

\author{
Kontakt \\ a,b,c,d Národní institut pro další \\ vzdělávání \\ Senovážné náměstí 25 \\ 11000 Praha \\ acakirpaloglu@nidv.cz \\ bodstrcilova@nidv.cz \\ cmusilova@nidv.cz \\ dbarinkova@nidv.cz
}

$\triangle$ Korespondence:

cakirpaloglu@nidv.cz

Copyright (C 2019 by the author and publisher, TBU in Zlín.

This work is licensed under the Creative Commons Attribution International License (CC BY).

$$
\text { open } 2 \text { access }
$$

\begin{abstract}
Abstrakt: Příspěvek se zaměřuje na potřeby a postoje ředitelů ve vztahu ke společnému vzdělávání v krajských sítích škol a školských zařízení vytvořených $v$ rámci individuálního projektu systémového Podpora společného vzdělávání $v$ pedagogické praxi (APIV B). Krajské sítě obsahují dohromady ve všech krajích celkem 355 mateřských, základních a středních škol, vyšších odborných škol a školských zařízení. Krajské sítě byly v rámci poptávky OP VVV vystavěny jako sítě, které potřebují podporu a pracují ve složitějších podmínkách $v$ oblasti inkluze, než je republikový průměr. Záměrem našeho příspěvku je popsat, jak se z pohledu ředitelů zapojených škol daří realizovat společné vzdělávání, $a$ to ve spojitosti $s$ legislativními změnami zavedenými v roce 2016. Dotazníkového šetření se zúčastnilo celkem 355 ředitelů škol a školských zařizení. Sběr dat časově kopíroval vstup škol do projektu v letech 2017-2019. Celkové výsledky šetření poukazují na skutečnost, že jako nejatraktivnější a zároveň nejpotřebnější téma pro své učitele $v$ rámci dalšího vzdělávání označili ředitelé zapojených škol oblast sociální interakce mezi učitelem, rodičem a žákem.
\end{abstract}

Klíčová slova: společné vzdělávání, APIV B, potřeby ředitelů, postoje ředitelů

\section{Inclusive education through the view of the principals of the regional network of schools and school facilities within the APIV B Project}

\begin{abstract}
The paper focuses on the needs and attitudes of school principals concerning inclusive education in the regional network of schools and school facilities created within the framework of the individual systemic project Supporting Inclusive Education in Teaching Practice (APIV B). The regional network is comprised of 355 nursery schools, primary and secondary schools, higher vocational schools and school facilities in all regions of the Czech Republic and was built following a mandate for OP VVV as a network that requires support and works in more complex conditions of inclusion than exist at the national average. Our paper aims to describe how far the implementation of inclusive education has succeeded from the perspective of the principals of the participating schools in connection with the school legislative changes introduced in 2016. A total of 355 principals and school facilities participated in the questionnaire survey. The data collection mirrored the entry of schools into the project in
\end{abstract}


2017-2019. The overall results of the survey indicate the fact that the principals of the participating schools identified the area of social interaction between teacher, parent and pupil as the most attractive to deal with, and at the same time the most crucial topic for their teachers within the context of further education.

Keywords: inclusive education, APIV B, school principal needs, school principal attitudes

\section{1 Úvod}

\subsection{Historie společného vzdělávání ve světě}

Pojmy inkluze a zejména školní inkluze nebo inkluzivní vzdělávání se oficiálně používají od doby konání konference ve španělském univerzitním městě Salamanka v roce 1994, na níž všechny evropské země ratifikovaly Deklaraci ze Salamanky a akční rámec pro speciální vzdělávání (UNESCO, 2019). Podpora inkluzivního vzdělávání byla později také potvrzena Akčním plánem vzdělávání pro všechny v Dakaru (UNESCO, 2000). Jako klíčový impuls pro rozvoj inkluzivního prostředí tuto událost uvádí i Pedagogický slovník, jež cituje z uvedeného prohlášení: „Princip inkluze implikuje, že běžné školy by měly vzdělávat všechny děti bez ohledu na jejich fyzické, intelektuální, emocionální, sociální, jazykové nebo jiné podmínky. Běžné školy $s$ inkluzivní orientací jsou nejefektivnějšími prostředky pro potlačení diskriminujících postojů, pro vznik vstřícných komunit, vytváření začleňující společnosti“ (Průcha, Walterová, \& Mareš, 2003, s. 85).

Přestože se inkluze dostala do povědomí většinové odborné a laické veřejnosti zejména v souvislosti s Deklarací ze Salamanky, fenomén inkluzivního vzdělávání se vyvíjí již od 60. let 20. století, a to především ve Velké Británii, Spojených státech amerických a Kanadě (Kratochvílová, 2019). V Kanadě vznikl požadavek na inkluzivní vzdělávání již v roce 1968 a byl uzákoněn v roce 1985. Stejně tak ve Spojených státech amerických bylo inkluzivní vzdělávání cíleně podporováno a rozvíjeno již od 70. let 20. století. Jak dále uvádí Kratochvílová, v tomto období se inkluzivní vzdělávání týkalo zejména marginalizovaných skupin a žáků se speciálními vzdělávacími potřebami (Kratochvílová, 2019). V mezinárodním měřítku je však inkluze stále více vnímána jako reforma, která podporuje a vítá rozmanitost všech žáků (Ainscow, 2005). Tato reforma mimo jiné postuluje, že cílem inkluzivního vzdělávání je odstranit sociální vyloučení, které je důsledkem postojů a reakcí na rasovou rozmanitost, rozdíly v sociálních třídách, etnickém původu, náboženství, pohlaví a schopnostech (Vitello, 1998). Ainscow zdůrazňuje, že vzdělání všem lidem bez ohledu na jejich rozdílnost je základním lidským právem a předpokladem pro spravedlivější společnost (Ainscow \& César, 2006). V následujících letech dochází $v$ mnoha evropských a mimoevropských zemích $k$ značné aktivitě, pokud jde o posun vzdělávací politiky a praxe proinkluzivním směrem (Ainscow \& Sandill, 2010).

Nicméně, souhlasíme s tvrzením Lechty, že po více než dvaceti letech od konference v Salamance má implementace inkluze vážné sociální, politické a ekonomické důsledky. Je zároveň odvážným dokumentem, který vyvolává i mnohé otázky a kritiku, při níž se upozorňuje zejména na nebezpečí předčasné, nedostatečně připravené inkluze prováděné zejména pod nátlakem různých politických institucí a nerespektující názory zainteresovaných odborníků (Lechta, 2016).

Přestože se vzdělávací politika v mnoha zemích skutečně začíná orientovat směrem ke společnému vzdělávání všech žáků, stále existuje značná nejistota ohledně toho, jak nejlépe postupovat v implementaci inkluzivních principů (Mittler, 2012). Za klíčové považujeme také zmínit, že neexistuje jednoznačný ucelený pohled na pochopení podstaty inkluze uvnitř jednotlivých zemí nebo dokonce i jednotlivých škol uvnitř stejného státu (Booth \& Ainscow, 1998). Dalším podstatným problémem, který je hodně diskutován napříč jednotlivými aktéry, je neúplná či pouze částečná akceptace filozofie 
inkluzivity. V návaznosti na diskuzi ohledně podstaty inkluze přináší Ainscow (Ainscow \& César, 2006, s. 15) podrobnou typologii způsobů nahližení na inkluzi: 1. Inkluze jako problematika vzdělávání žáků se zdravotním postižením a vůbec žáků, kteři jsou zařazeni do kategorie „se speciálními vzdělávacími potřebami"; 2. Inkluze jako reakce na disciplinární vyloučení, 3. Inkluze ve vztahu ke všem skupinám, které jsou ohrožené sociálním vyloučením, 4. Inkluze jako rozvoj školy pro všechny, 5. Inkluze jako "Vzdělávání pro všechny", 6. Inkluze jako principiální př́stup ke vzdělávání a společnosti. Hájková a Strnadová uvádí, že $v$ zavádění inkluze existují minimálně dva vývojové stupně, které můžeme ve vzdělávacích systémech řady zemí Evropy pozorovat a které se často objevují paralelně. $\checkmark$ prvním př́ipadě se setkáváme se začleňováním žáků, kteří byli dříve z edukačního procesu z různých důvodů úplně vyloučeni. Nejčastějším důvodem pro vyloučení bylo postižení či kulturní odlišnost žáka. Druhá fáze inkluze směřuje $k$ tomu, že všechny děti z jedné územní oblasti navštěvují stejnou místní školu a jsou společně vzdělávány přiměřeně svým zájmům, schopnostem a nadání. Tato koncepce s sebou však přináší praktický předpoklad, že se všechny školy otevřou všem dětem a strukturálně se změní tak, aby jako inkluzivní vzdělávací zařízení začleňovaly všechny žáky (Hájková \& Strnadová, 2010). Jiní autoři vymezují podstatné aspekty, které jsou pro samotný proces inkluze považovány za velmi důležité. Zahrnují mezi nimi další vzdělávání pedagogických pracovníků směrem k inkluzi, zdroje, školskou legislativu a pedagogy (De Boer, Pijl, \& Minnaert, 2011). Praktická implementace inkluze $v$ běžných školách zdaleka není jednoduchým procesem, přičemž významnou roli hraje právě nejasné vymezení inkluze a nejistota či nedůvěra ohledně jejího přínosu pro celou společnost.

\subsection{Společné vzdělávání v ČR}

V současné době se problematika inkluzivního neboli společného vzdělávání široce diskutuje jak $v$ českých médiích, tak $\mathrm{i}$ jinde ve veřejném prostoru. $K$ naplnění vize inkluzivního a kvalitního vzdělávacího systému přispěly nedávno přijaté změny ve školské legislativě. $V$ posledních letech zvolilo inkluzivní vzdělávání jako jednu ze svých základních strategií i Ministerstvo školství, mládeže a tělovýchovy (MŠMT) a deklaruje ji v řadě strategických dokumentů. Otázka vzdělávání všech dětí, žáků a studentů v rámci hlavního vzdělávacího proudu se tak aktuálně stala prioritou MŠMT. Vzdělávací politika směrem k inkluzi je zakotvená ve Strategii vzdělávací politiky do roku 2020 (MŠMT, 2019d), která obsahuje tři klíčové priority: snižování nerovnosti ve vzdělávání, podporu kvalitní výuky a učitelů, odpovědné a efektivní rízení vzdělávacího systému.

Z uvedeného dokumentu pak vychází Dlouhodobý záměr vzdělávání a rozvoje vzdělávací soustavy České republiky na období 2015-2020 (MŠMT, 2019e) z března 2015, jež navazuje na Dlouhodobý záměr vzdělávání a rozvoje vzdělávací soustavy České republiky na období 2011-2015 (MŠMT, 2019c). Uvedený dokument zakotvuje záměry, cíle a kritéria vzdělávací politiky, určuje rámec dlouhodobých záměrů krajů a sjednocuje př́stup státu a jednotlivých krajů zejména v oblasti nastavení parametrů vzdělávací soustavy. Ve vztahu $\mathrm{k}$ inkluzivnímu vzdělávání je důležitá kapitola $\mathrm{G}$, která se podrobně věnuje rovným př́ležitostem ve vzdělávání, poradenství, vzdělávání žáků se SVP a zdůrazňuje, že „osobní a společenské okolnosti, jako je pohlaví, etnický původ či rodinné zázemí, nepředstavují překážky při dosahování maxima vzdělávacího potenciálu.“ (MŠMT, 2019e, s. 47). V této oblasti vymezuje jako základní cíl „zvýšit schopnost vzdělávacího systému vytvářet podmínky a uplatňovat účinné postupy pro efektivní prevenci a kompenzaci zdravotních, sociálních, kulturních a jiných osobnostních znevýhodnění tak, aby nerovnosti $v$ dosahovaných výsledcích byly co nejméně předurčovány faktory, které nemůže jedinec ovlivnit. "(MŠMT, 2019e, s. 49).

Poslední novela školského zákona, která od 1. záŕi 2016, rovněž garantuje právo dětí na tzv. podpůrná opatření, pomoc překonávat jejich znevýhodnění, at' už se jedná o děti a žáky ze sociálně znevýhodněného a kulturně odlišného prostředí, děti a žáky zdravotně postižené a znevýhodněné nebo žáky (mimořádně) nadané.

Navazujícím dokumentem současnosti ve vztahu k inkluzivnímu vzdělávání je Akční plán inkluzivního vzdělávání na období 2016-2018 (MŠMT, 2019a) a Akční plán inkluzivního vzdělávání na období 2019-2020 (MŠMT, 2019b), který z priorit výše zmíněného Dlouhodobého záměru vychází a MŠMT 
jej vydalo ve spolupráci s dalšími partnery. Mimo jiné obsahuje opatření na podporu rovných přiležitostí a spravedlivého přístupu ke kvalitnímu vzdělávání, včetně prevence a nápravy předčasných odchodů ze vzdělávání. Dokument dále reflektuje navržené legislativní změny v novele školského zákona. V průběhu roku 2016 nahradilo Ministerstvo školství mládeže a tělovýchovy, termín inkluze na svých stránkách pojmem „společné vzděláváni“. Tímto pojmem MŠMT postupně nahrazuje pojem „inkluze“ či „inkluzivní vzdělávání“ rovněž v odborných materiálech. V materiálu s názvem Základní informace ke společnému vzdělávání, které vydalo MŠMT (MŠMT, 2019a) garantuje společné vzdělávání všech žáků v hlavním vzdělávacím proudu, pokud je to v nejlepším zájmu dítěte a slibuje podporu každého žáka, který ji potřebuje, včetně nároku na finanční podporu přiznaných podpůrných opatření v plné výši.

Průběh společného vzdělávání dětí a žáků ve všech stupních vzdělávací soustavy hodnotí ve svých výročních zprávách rovněž Česká školní inspekce, kde např. ve výroční zprávě za školní rok 2017/2018 uvádí, že v současné době by měl vzdělávací systém poskytovat všem dětem v maximální míre rovné vzdělávací přiležitosti. S tím souvisí i poskytování individuální podpory pro rozvoj kognitivních a sociálních dovedností dětem, které ji potřebují.

\subsection{Výzkumy vztahující se k inkluzivnímu vzdělávání v ČR}

Se změnami v české vzdělávací soustavě se tématu inkluze začala věnovat řada odborníků $v$ ČR. Jak uvádí Bartoňová a Vítková (2010) český vzdělávací systém koncepčně reflektuje požadavky evropské společnosti, proto se novým podmínkám přizpůsobují i pedagogické fakulty, jež se v posledních letech zapojují do mnoha projektů souvisejících s rozvojem inkluzivního vzdělávání. Na poli výzkumném rovněž začínají být realizována výzkumná šetření zabývající se výsledky v oblasti inkluzivního vzdělávání. Z realizovaných výzkumů uved'me alespoň výzkum Hájkové a kolektivu (Hájková, Pastieriková, Klusáčková, Daşkın, \& Košák, 2019), Analýzy potřeb pedagogických pracovníků v oblasti inkluzivního vzdělávání, jenž je součástí výstupů projektu „Systémová podpora inkluzivního vzdělávání v ČR“ (www.inkluze.upol.cz), kde byly zkoumány zkušenosti a vzdělávací potřeby pedagogů $\checkmark$ regionálním školství při práci s dětmi se speciálními vzdělávacími potřebami. Dílčím cílem tohoto výzkumu bylo zmapování zájmu pedagogických pracovníků o jednotlivé typy DVPP. Straková, která zkoumala postoje ke společnému vzdělávání v širším kontextu postojů k diferenciaci vzdělávacích drah, mimo jiných výsledků poukázala na rozporuplné postoje veřejnosti ke společnému vzdělávání zejména pak na nedostatek informací (Straková, Simonová, \& Friedlaenderová, 2019). Souhlasně i s jinými výzkumy, také Štech zdůrazňuje nedostatečné vzdělávání pedagogů, at' už se jedná o vzdělávání v pregraduální prípravě či v rámci dalšího vzdělávání. Jako problematickou oblast vzdělávání identifikuje zejména individualizovanou práci se žákem se SVP a také protichůdné informace při vysvětlování podstaty inkluze různými institucemi (Štech, 2018).

\section{Metodologie výzkumu}

\subsection{Cíle projektu a Krajské sítě podpořených škol}

Projekt Podpora společného vzdělávání v pedagogické praxi (APIV B) si klade za cíl zvýšit podporu společného vzdělávání u všech zainteresovaných skupin (odborné, pedagogické i široké veřejnosti) a posílit osobnostní a profesní kompetence pedagogických pracovníků (managementu škol a školských zařízení, učitelů, vychovatelů, pedagogů volného času aj.) potřebné k realizaci společného vzdělávání v předškolním, základním, středním a zájmovém a neformálním vzdělávání. Jednou z aktivit projektu v letech 2016-2018 bylo vytvoření krajských sítí spolupracujících škol a školských zařízení. Projekt předpokládal zapojení 24 škol a školských zařízení v každém ze 14 regionů ČR, dohromady tedy 336 škol a školských zařizení. Skupina 24 škol v každém regionu měla získat podporu v oblasti společného vzdělávání, přičemž polovina škol $v$ každém kraji má být také príijemcem portfolia rozšířených vzdělávacích, mentorských a koučovacích služeb a služeb externích odborníků (speciálních pedagogů, psychologů, metodiků DVPP aj.). Takto podpořené školy mají vytvořit základ krajských sítí škol 
vzájemně spolupracujících v oblasti společného vzdělávání například předáváním př́ikladů dobré praxe atd. Tyto krajské sítě škol zapojených do projektu byly v letech 2017-2018 vytvořeny a celkem se do nich zapojilo 355 mateřských, základních, středních, vyšších odborných a školských zařízení ve všech krajích vČR. Součástí vstupu škol do projektu bylo také výzkumné šetření mezi jejich řediteli a pedagogy. Výzkum Krajských sítí zapojených škol byl realizován v období od listopadu 2017 do ledna 2019 jako kvantitativní vstupní šetření v rámci projektu. Uvedené šetření je hlavním zdrojem informací a závěrů následující statě.

\section{Cíle vstupního šetření Krajských sítí zapojených škol}

Primárním cílem vstupního kvantitativního šetření bylo popsat informovanost, dosavadní způsoby podpory a zejména aktuální potřeby ředitelů a pedagogů Krajských sítí zapojených škol v době jejich vstupu do projektu. Tyto informace měly sloužit primárně pro práci krajských konzultantů, kteří podle nich a ve spolupráci se školními konzultanty mohli škole nastavit individuálně zacílenou podporu $\checkmark$ oblasti inkluze. Agregovaná data škol však mohli použít pro svou práci také koučové a mentoři při svém vstupu do konkrétní školy. Na základě výstupů z výzkumu bylo možné zjistit i priority obsahu vzdělávacích modulů dalšího vzdělávání ředitelů a pedagogů. Výsledky výzkumu poslouží také jako popis počátečního stavu při závěrečném vyhodnocení celkového dopadu podpory $v$ rámci projektu APIV B v roce 2021 , kdy podpora z projektu školám skončí.

\subsection{Metodika výběru škol do krajských sítí}

Vzhledem $k$ tomu, že výsledným výběrovým souborem $v$ každém regionu mělo být 24 škol, bylo s ohledem na odhadovanou ochotu k zapojení do projektu vybráno z databáze škol (MŠMT) v každém regionu cca 100-120 škol. Oslovení a následný výběr škol byl realizován primárně na základě ochoty škol se zapojit do projektu, sekundárně se v rámci škol ochotných ke spolupráci kontrolovala vyvážená struktura výběrového vzorku dle jednotlivých typů škol. V př́pravné fázi byly z celkové databáze škol včetně školských zařízení postupně vyřazeny zrušené školy nebo školská zařízení, speciální školy, školy spolupracující vjiných projektech spodporou inkluzivního vzdělávání a sohledem na nutnost poskytnutí bagatelní podpory min. pro osmičlenný tým pedagogů všech spolupracujících škol i školy s malým počtem učitelů (ve většině krajů bylo kritérium nastaveno na 20 a více učitelů v MŠ a 25 a více učitelů pro ZŠ, SŠ, VOŠ, SVČ). Výjimkou se stal Karlovarský kraj, kde byl z důvodu vyššího zastoupení menších škol snižen požadovaný počet na min. 15 učitelů na školu. Zároveň tento filtr vyhovoval předpokladům co největšího zásahu $v$ rámci týmu školy, multiplikace nově získaných poznatků a dovedností a spolupráce ve škole $v$ oblastech podpory. $V$ další fázi výběru škol a školských zařízení bylo použito kritérium maximální heterogenity běžných škol z hlediska zastoupení jednotlivých diagnostikovaných speciálních vzdělávacích potřeb (dále jen „SVP“). Přednostně byly vybírány školy s vyšším indexem heterogenity, tedy školy s vyšším zastoupením různých typů žáků se SVP. Index heterogenity byl definován jako počet různých typů postižení, které jsou zastoupeny $\checkmark$ jednotlivých školách bez ohledu na počet žáků diagnostikovaných daným typem postižení. Index heterogenity nabývá hodnot $0-9$. Zdrojem výpočtu jsou data MŠMT. Do výpočtu jsou zahrnuty následující druhy postižení, poruch nebo vad: mentální postižení, sluchové postižení, zrakové postižení, závažné vady řeči, tělesně postižení, kombinované vady, závažné vývojové poruchy učení, závažné vývojové poruchy chování a poruchy autistického spektra. $V$ rámci výběru byly upřednostněny školy s indexem 3+ (průměr za běžné školy ČR je 1,5; průměr za výběr škol: 2,9). Celkový průměrný index reálně zapojených škol je 3,8 což velmi dobře odpovídá cílenému výběru škol. U zapojených ZUŠ a SVČ je hodnota indexu neuvedena s ohledem na absenci dat MŠMT.

Na základě výše zmíněných kritérií bylo vybráno celkem 1516 škol ve 14 regionech ČR. V případě, že indikované školy neprojevily zájem o zapojení do projektu, nebo v případech, kdy byla databáze bez úspěchu vyčerpána, bylo nezbytné seznam doplnit v souladu s uvedenými kritérii při úpravě některých parametrů. 
Pro konstrukci výběrového vzorku byl použit pravděpodobnostní vícestupňový statistický výběr škol a školských zařízení, který byl záměrně přizpůsoben podmínkám tvorby krajských sítí škol a školských zařízení. Z výše zmíněných důvodů výběrový vzorek nelze pokládat za reprezentativní vzhledem ke všem školám v ČR.

\subsection{Výzkumný soubor a použitá metodologie}

Výběrový soubor respondentů tvořili ředitelé krajských sítí zapojených škol a školských zařízení $(N=355)$ a učitelé těchto škol $(N=6349)$. Záměr uplatnit data dotazníku pro nastavení individuální podpory škole zapůsobil motivačně, $100 \%$ ředitelů dotazníky kompletně vyplnilo a poslalo zpět. U dotazníku učitelů bylo nutné doporučit hranici minimální návratnosti na 35 \% za školu, aby bylo možné data agregovat zejména u malých mateřských škol a interpretovat je za učitele i na úrovni školy. Návratnost dotazníků učitelů je 62 \%. Proces motivace a urgování škol probíhal po celou dobu sběru dat s výjimkou prázdninového období. Průběh dotazování se flexibilně přizpůsoboval časovému období nabírání nových škol. Sběr dat na školách započal v 11/2017 a skončil v 01/2019, což bylo nutné vzít v potaz zejména při interpretaci otázek s časovým kontextem.

Pro šetření byl použit online dotazník ve variantách pro zmíněné dva výběrové vzorky respondentů. Dotazníky z větší části řešily potřeby vlastního projektu, ale byly v konstrukci inspirovány i dotazníkem ze šetření z roku 2017 („Dopady reformy“, 2019). Vzhledem k důležitosti šetření v procesu nastavení podpory škol byla koncepce připomínkována realizačním týmem a experty na školní problematiku a pedagogický výzkum. Následovala pilotáž dotazníků na všech typech škol a školských zařízení. $\checkmark$ rámci ní byly testovány zejména srozumitelnost, obtížnost dotazů a délka vyplňování. Distribuce dotazníků proběhla centrálně přes hromadný link určený učitelům (anonymní $v$ rámci školy) a link určený ředitelům s identifikací školy. Doba vyplňování dotazníku se pohybovala kolem 20 minut.

Dotazníky zahrnovaly oblasti zaměřené na zkušenosti se zvládáním heterogenní skupiny a zvládáním práce $s$ dětmi se SVP, dále na obtíže a bariéry $v$ zajištění podpory vzdělávání dětí/žáků $s$ potřebou podpůrných opatření v potřebné kvalitě a na konkrétní překážky $v$ zajištění podpory vzdělávání těchto dětí/žáků. Další témata zahrnovala okruh podpory pedagogů $v$ oblasti inkluzivního vzdělávání před vstupem do projektu (obsah $\mathrm{i}$ forma podpory) a potřeby pedagogů $\mathrm{v}$ oblasti inkluzivního vzdělávání, stav metodické podpory na škole, porozumění obsahu doporučení školského poradenského pracoviště a stav spolupráce pedagogů s asistenty. Tato témata byla zaměřena na popis podmínek a stavu škol v oblasti inkluze a mohla tak ve spojení s daty o celkových počtech dětí a žáků, počtech pedagogů a počtech dětí s konkrétními typy poruch popsat stav školy a její potřeby. Poslední okruh témat dotazníku spiše doplňoval stávající zaměření a věnoval se vnímání důsledků změn, které vešly v podobě novely školského zákona v platnost 1. 9. 2016, tj. informovanosti v jednotlivých oblastech a podpoře úkonů v oblasti administrativy.

Sběr dat probíhal elektronicky prostřednictvím otevřené platformy Google Forms, která splňuje metodologicko-výzkumná kritéria relevantnosti on-line šetření jen částečně. Konkrétně byl např. použit př́stup škol přes individuální heslo, ale systém již neumožňuje použít pokročilé filtrování při kladení otázek a nemá standardní formu exportu dat u multi-výběrového typu otázek. Tyto limity sběru dat byly vypořádány zařazením doplňkových otázek nebo nastavením čistících procedur dat u problematických otázek apod.

Získaná data byla následně statisticky zpracována za použití statistického programu SPSS a MS Excel. Vzhledem $\mathrm{k}$ účelu výzkumného šetření v rámci projektu nebyly prováděny testy významnosti.

Plánované výstupy ze šetření zahrnují:

- reporty pro školy k nastavení individuální strategie podpory a pro mentory a kouče ke vstupu na školy,

- priority potřeb ředitelů a učitelů k nastavení obsahu DVPP v rámci projektu,

- zprávy z Krajských sítí zapojených škol a školských zařízení s hodnocením popisu jejich prostředí a prioritních potřeb. 


\subsection{Popis výzkumného souboru}

\section{Struktura krajských sítí škol}

Většinu výběrového souboru (viz. Graf 1 ) tvoří školy základní - 188 škol (53 \%), dále jde o školy mateřské - 95 škol (27 \%) a střední školy - 62 (18\%). Zbytek vzorku tvoří základní umělecké školy $-6(2 \%)$, vyšší odborné školy - $2(0,6 \%)$ a střediska volného času - 2 (0,6 \%).

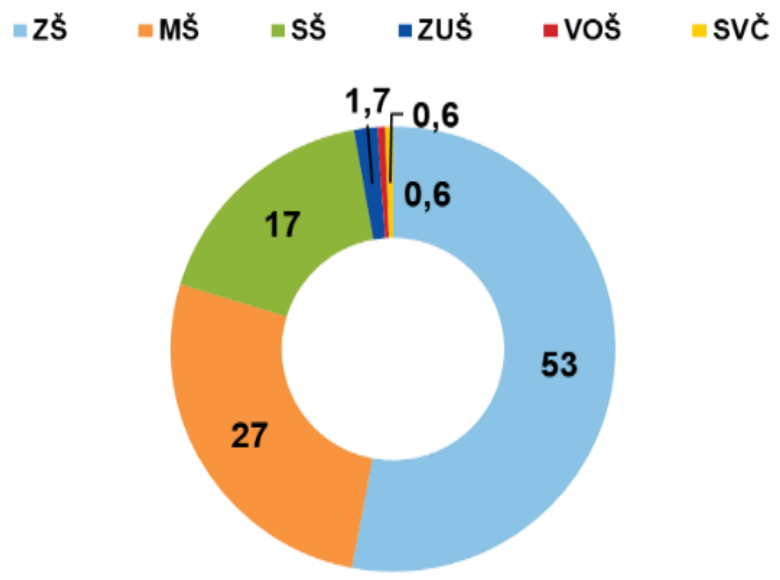

Graf 1 Struktura krajské sítě dle typu školy

Výsledný soubor víceméně odpovídá zamýšlené struktuře a odráží reálné komplikace se zapojením mateřských škol do projektu. Jejich nižší počet byl saturován vyšším zastoupením škol základních.

Tabulka 1

Struktura krajské sitě škol dle typu školy

\begin{tabular}{lllll}
\hline Druh školního zařízení & MŠ & ZŠ & SŠ & Ostatní \\
\hline Výběr škol & $32 \%$ & $46 \%$ & $18 \%$ & $4 \%$ \\
Skutečná struktura krajské sítě & $27 \%$ & $53 \%$ & $18 \%$ & $3 \%$ \\
\hline
\end{tabular}

Vzhledem k nízkému počtu (a tedy i statisticky nízké vypovídací hodnotě získaných odpovědí) u ZUŠ, VOŠ a SVČ budeme v dalším textu tř́́dění dle typu školy posuzovat pouze školy mateřské, základní a střední (viz. Tabulka 1). Výsledky šetření za ZUŠ, VOŠ a SVČ byly pro účely projektu zpracovány kvalitativním způsobem.

Základním požadavkem konečného výběrového souboru bylo minimálně 24 škol zapojených škol $\checkmark$ každém kraji a struktura výběrového vzorku této podmínce velmi dobře odpovídá. U 9 krajů je toto zastoupení dodrženo přesně, v Pardubickém kraji se zapojilo 25 škol, v Královehradeckém a Moravskoslezském kraji 29 škol a v Olomouckém kraji 30 škol (viz. Graf 2). Navýšení počtu zapojených škol v počátku projektu tvoří celkovou rezervu nutnou k dodržení př́slušných indikátorů projektu. 


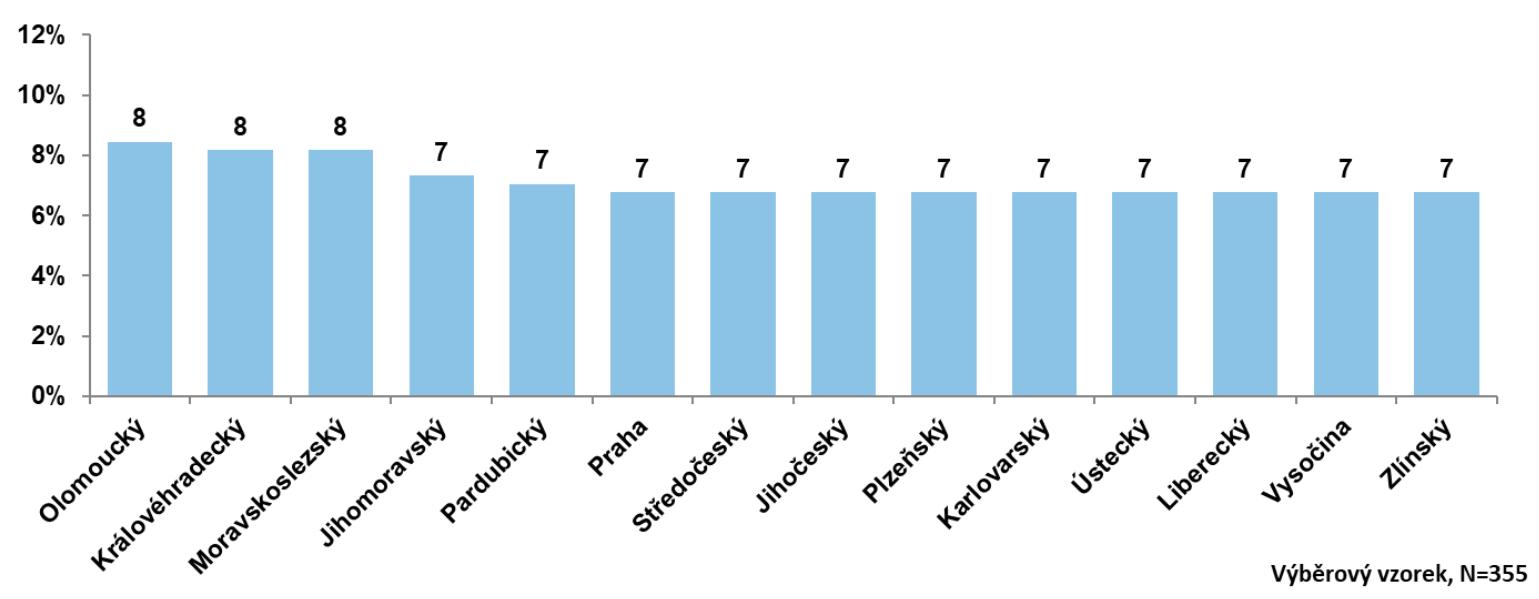

Graf 2 Struktura krajské sítě škol dle krajů

Mezi největší školy s více než 500 dětmi/žáky patří necelých 16 \% vzorku zapojených škol, ale nejvíce zapojených škol má 301 až 500 žáků/dětí (22 \%) nebo 101 až 200 dětí/žáků (22 \%). 19 \% zapojených školských subjektů navštěvuje méně než 100 žáků. 201 až 300 žáků má $18 \%$ škol. Výběrový soubor tak odpovídá podmínce výběru, který záměrně cílil na větší školy.

\section{Složení výběrového souboru ředitelů}

V kontextu šetření a celého projektu je výběrový soubor ředitelů popsán zejména různými typy zkušeností spojených s oblastí společného vzdělávání. Většina ředitelů zapojených škol $v$ šetření deklarovala, že jejich pedagogická praxe je delší než 10 let (332 ředitelů $-94 \%$ ), pouze necelých $5 \%$ ředitelů má pedagogickou praxi v rozmezí $6-10$ let a jen 6 ředitelů deklarovalo pedagogickou praxi do 5 let.

Nad 10 let v manažerské funkci pracuje necelá polovina vzorku ředitelů zapojených škol (49\%), z toho u $29 \%$ je to i více než 16 let. $22 \%$ ředitelů deklarovalo manažerskou zkušenost 6-10 let. Zbývající část vzorku má méně zkušeností - u $19 \%$ ředitelů je to 2-5 let a u $9 \%$ ředitelů jde o zkušenost na manažerské pozici trvající méně než rok.

Osobní zkušenost se začleňováním dětí/žáků se SVP do vzdělávání má většina ředitelů zapojených škol (92 \%), zkušenost se spoluprací s asistentem pedagoga ve vzdělávání mají tři čtvrtiny ředitelů. Pouze v necelých 14 \% jsou ředitelé zapojených škol zároveň i speciálními pedagogy. Poměrně dobré zkušenosti byly u výběrového vzorku ředitelů zaznamenány i se zvládáním heterogenní skupiny dětí, 55 \% má tuto zkušenost delší než 10 let, 42 \% dokonce víc než 16 let. 9 \% tuto zkušenost nemá vůbec.

Výběrový vzorek ředitelů vykazuje poměrně velkou zkušenost ředitelů v pedagogické a manažerské praxi, ale i osobní zkušenost se začleňováním dětí/žáků se SVP nebo se spoluprací s asistenty pedagoga. $\checkmark$ rámci celkově objektivně náročnějších podmínek voblasti heterogenního složení dětí/žáků ve školách krajské sítě je informace o zkušenosti ředitelů důležitým zjištěním.

\subsection{Interpretace výsledků dílči analýzy dotazníkového šetření pro ředitele zapojených škol a školských zařizení}

Hlavním cílem této dílčí analýzy je zjistit, jak se daři školám a školským zařízením zapojených v krajských sítích realizovat společné vzdělávání a co z pohledu svých ředitelů potřebují pro zlepšení svého stavu.

Související dílčí cíle byly zaměřeny:

1. na analýzu dosavadního stavu podpory pedagogických pracovníků v oblasti společného vzdělávání,

2. na analýzu vzdělávacích potřeb pedagogických pracovníků. 
Ad 1. Pro analýzu dosavadního stavu dalšího vzdělávání pedagogických pracovníků voblasti společného vzdělávání z pohledu ředitelů posloužila otázka: „Pokud jste získali podporu v oblasti dalšího vzdělávání zaměřeného na inkluzi, na jakou konkrétní oblast bylo zaměřeno?"

\section{Ř: Pokud jste získali podporu v oblasti dalšího vzdělávání zaměřeného na inkluzi, na jakou konkrétni oblast bylo zaměřeno?}

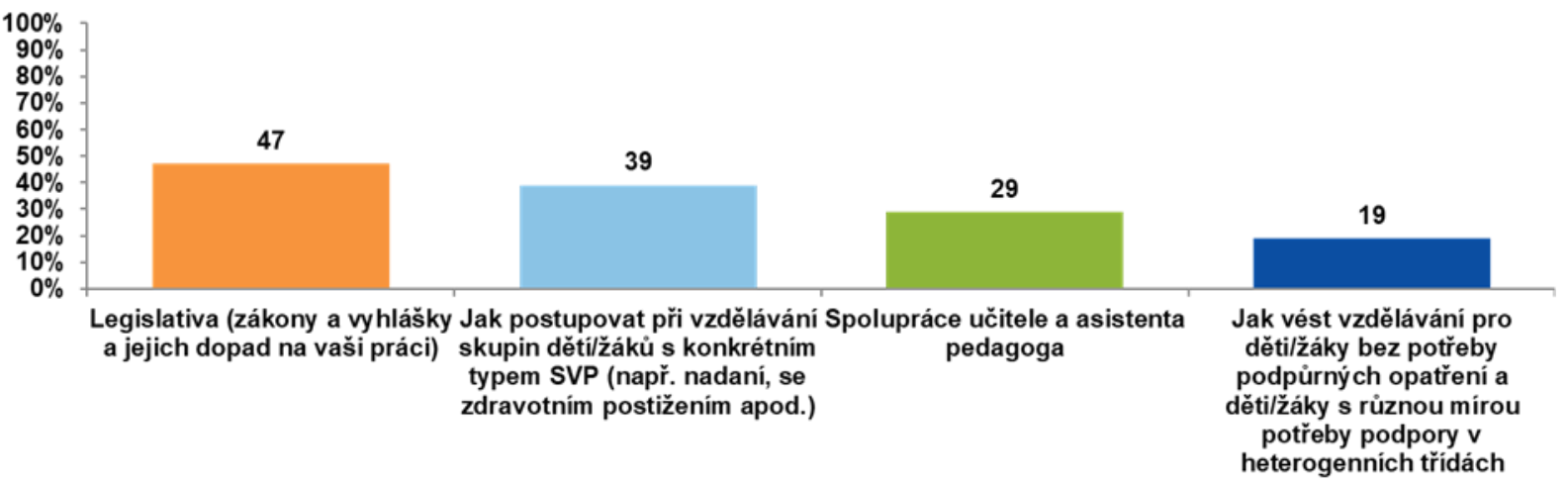

Výběrový vzorek, $\mathrm{N}=355$

Graf 3 Podpora v oblasti společného vzdělávání z pohledu ředitelů

Ředitelé zapojených škol uvádějí, že nejhojněji využitá oblast podpory v oblasti dalšího vzdělávání zaměřeného na inkluzi na jejich školách byla Legislativa (47 \% škol) (viz. Graf 3). S desetiprocentními odstupy dále následují témata Jak postupovat při vzdělávání skupin dětí/žáků s konkrétním typem SVP (39\%), Spolupráce učitele a asistenta pedagoga (29 \%) a Jak vést vzdělávání pro děti/žáky bez potřeby $\mathrm{PO}$ a děti/žáky s různou mírou potřeby PO v heterogenních tř́́dách (19 \%).

\section{Ř: Pokud jste získali podporu v oblasti dalšího vzdělávání zaměěeného na} inkluzi, na jakou konkrétní oblast bylo zaměřeno?

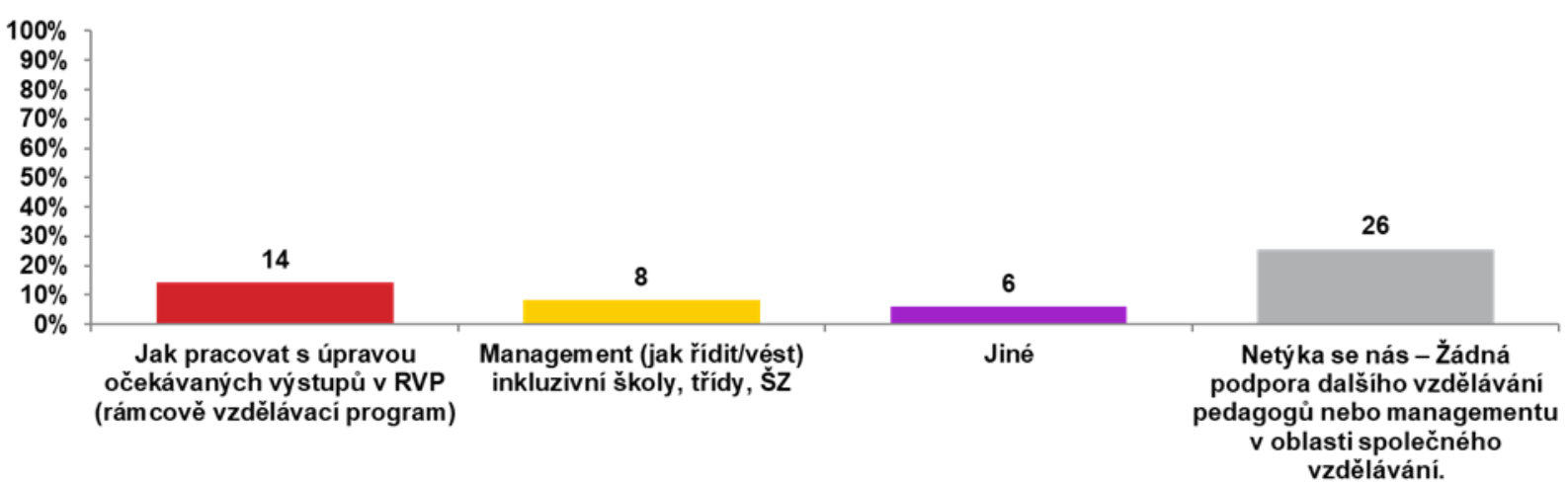

Výběrový vzorek, $\mathrm{N}=355$

Graf 4 Podpora v oblasti společného vzdělávání z pohledu ředitelů

Již jako méně četná se ukázala oblast podpory Jak pracovat $s$ úpravou očekávaných výstupů v RVP (14 \%) a Management inkluzivní školy, třídy, Šz (8 \%) (viz. Graf 4). V souladu s předešlou otázkou $26 \%$ ředitelů sdělilo, že žádnou podporu společného vzdělávání jejich škola nečerpala. Nejnižší míru podpory získaly dle údajů od svých ředitelů zapojené střední školy (39 \% bez podpory), nejvyšší pak základní (19 \% bez podpory). Posloupnost míry čerpání daných podpor dalšího vzdělávání zůstává u všech typů škol stejná. Drobnou výjimku nalezneme u středních škol, kde je podpora v oblasti 
Jak pracovat s úpravou očekávaných výstupů v RVP (3 \% středních škol) až za Managementem (6 \%). U zapojených mateřských škol se podíly čerpání podpor bliží celkovým průměrům (odchylky do $5 \%$ ). U základních jsou tyto hodnoty vyšší až na podporu v oblasti Managementu (7 \%). Výrazně vyšší podíl základních škol (ve srovnání s celkovými průměry) získal podporu v oblastech Jak postupovat při vzdělávání skupin dětí/žáků s konkrétním typem SVP (47 \%) a Spolupráce učitele a asistenta pedagoga ( 37 \% zapojených základních škol). Podíly podpořených středních škol jsou, jak již bylo zmíněno, nižší, a to ve všech oblastech o 13-16 \% oproti celkovému průměru (s výjimkou Managementu).

Ad 2. Pro zjištění aktuálních vzdělávacích potřeb pedagogických pracovníků v rámci společného vzdělávání z pohledu ředitelů zapojených škol posloužily otázky: „Jaká témata by byla pro učitele potřebná a atraktivní v rámci dalšího vzdělávání?", "Na co by mělo být zaměřeno DVPP v oblasti společného vzdělávání pro management školy?" a otázka "Které z forem podpory by potřebovali vaši učitelé v oblasti společného vzdělávání?"

\section{Ǩ: Vyberte, jaká témata by byla pro vaše učitele potřebná a atraktivní v rámci dalšího vzdělávání?}

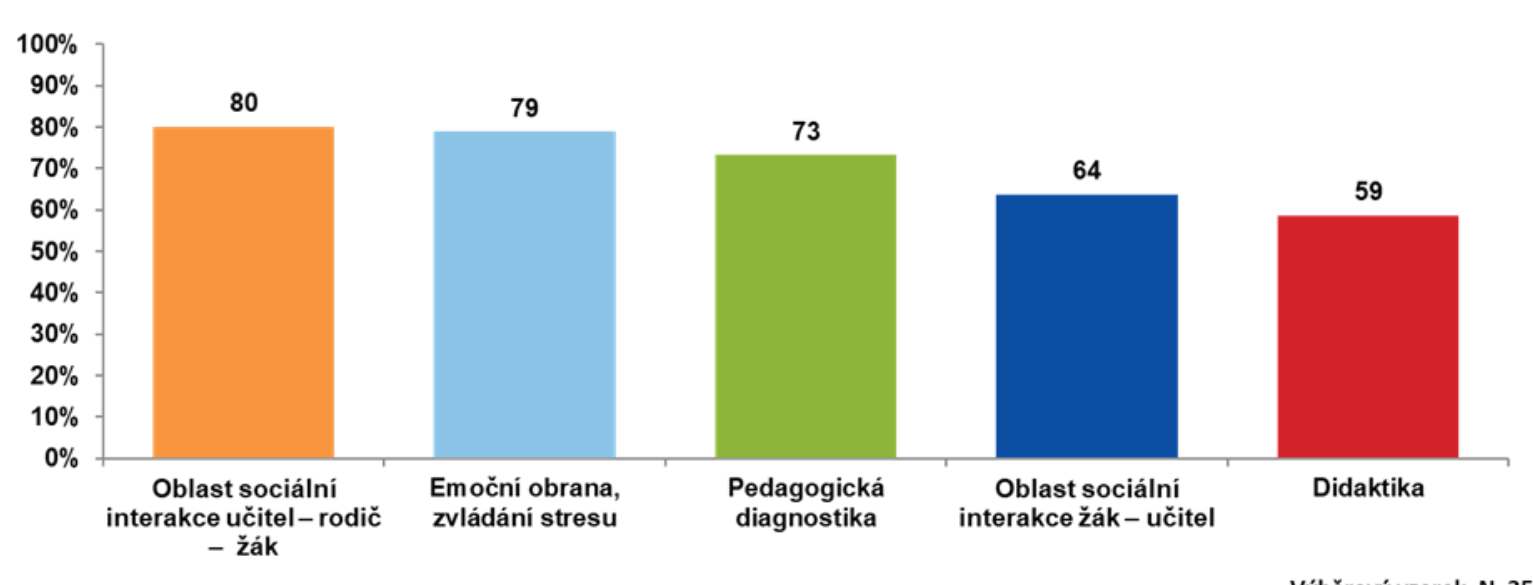

Graf 5 Výběr potřebných a atraktivních témat v rámci dalšího vzdělávání pro pedagogy z pohledu ředitelů škol

Ředitelé zapojených škol vnímají jako nejvíce atraktivní a potřebná témata pro další vzdělávání svých učitelů Oblast sociální interakce učitel-rodič-žák (80 \% ředitelů) a Emoční obranu, zvládání stresu (79 \%) (viz. Graf 5). V těsném závěsu se umístila Pedagogická diagnostika (73 \% ředitelů). S odstupem následuji témata Oblast sociální interakce žák-učitel (64\%) a Didaktika (59\%). Necelá polovina ředitelů (40-46\%) pak považuje za atraktivní a potřebná témata pro učitele Oblast sociální interakce žák-žák (46 \%) a Oblast osobní a profesní kultivace (40 \%). Téma Oborově předmětová oblast již označila pouze čtvrtina ředitelů zapojených škol.

Posloupnost preferencí jednotlivých témat se velmi liší podle typu školy, nicméně první trojice zůstává. Ředitelé zapojených mateřských škol zhodnotili témata v tomto pořadí: Pedagogická diagnostika, Oblast sociální interakce učitel-rodič-žák, Emoční obrana, zvládání stresu, Didaktika, Oblast osobní a profesní kultivace. U zapojených základních škol žebříček kopíruje celkové pořadí. Ředitelé zapojených středních škol považují za nejvýznamnější tato témata: Emoční obrana, zvládání stresu, Oblast sociální interakce učitel-rodič-žák, Oblast sociální interakce žák-učitel, Pedagogická diagnostika a Didaktika. Lze konstatovat, že ředitelé zapojených škol celkově vnímají další vzdělávání svých učitelů jako významné. Všechna sledovaná témata získala nezanedbatelné preference (minimálně $25 \%$ ).

Ředitelé jako nejvýznamnější součást managementu školy mají preference témat dalšího vzdělávání podle předpokladu odlišné. Na vrchol pořadí umístili administrativu (75 \%), přičemž největší zájem je 
v této oblasti identifikován u mateřských škol (81 \%). Většina ředitelů ze zapojených škol spíše zvládá administrativu spojenou s poskytováním podpůrných opatření (74 \%), ale jen $10 \%$ zvládá administrativu zcela. Největší problém způsobují úkony spojené $s$ administrativou obecně, výkaznictvím a zpracováním IVP, plánu pedagogické podpory a s tím související agendy. Zhruba třetina oslovených ředitelů považuje některý $z$ administrativních úkonů spojených $\mathrm{s}$ poskytováním podpůrných opatření za časově náročný a zatěžující. Na druhém místě se nachází legislativa z oblasti společného vzdělávání. Toto téma bylo mohutně podpořeno z operačního programu, a i když by se na první pohled mohlo zdát, že je školám již jasné, není tomu tak. Odhlédneme-li od možnosti, zda nebyla odpověd' v dotazníku vnímána spíše jako obecné téma legislativy ve školství než uvedené téma legislativy v oblasti společného vzdělávání, pak se lze domnívat, že počáteční zájem o další vzdělávání pedagogických pracovníků v oblasti legislativy souvisel se schválením novely školského zákona o vzdělávání žáků se speciálními vzdělávacími potřebami, ale nyní bude motivem tohoto zájmu nejspíše míra nejistoty při uplatňování norem a opatření v pedagogické praxi.

$S$ velmi malými odstupy jsou téměř dvěma třetinami ředitelů žádána související témata z oblasti podpory komunikace uvnitř pedagogického sboru a komunikace s poradenským zařízením (58 \%) a nastavení strategie poradenského pracoviště školy (56\%). Pro polovinu ředitelů je atraktivní téma také školní vzdělávací plán (52 \%) a škola v síti služeb (46 \%), které obnáší služby pedagogickopsychologických poraden, speciálně-pedagogických center, OSPOD nebo neziskového sektoru. Přibližně třetinu škol krajské sítě zajímají témata spolupráce s ostatními školami (34 \%), strategický plán přechodu od neinkluzivní školy na inkluzivní ( $30 \%)$ nebo kurikulární reforma v oblasti společného vzdělávání (29\%).

Zajímavá jsou také data k preferenci forem služeb, spolupráce nebo vzdělávání, které měli ředitelé zvolit pro své učitele ve sledované oblasti (viz. Graf 6). Obvykle preferované další vzdělávání pedagogů nahradilo poradenství expertů v poskytování podpory dětí/žáků s potřebou podpůrných opatření. Tuto odpověd' zvolilo 83 \% ředitelů škol krajských sítí a preferují je všechny typy škol. U více než dvou třetin ředitelů (69\%) je stále oblíbené další vzdělávání. S malým statistickým rozdílem následují spolupráce s dětským psychologem (66 \%) a se speciálním pedagogem (63\%). Potřebné jsou pro učitele i informace o funkčnosti podpůrných pomůcek pro konkrétní děti/žáky v rámci podpůrných opatření (62\%). Mentoring jako žádanou formu individuální podpory zvolila téměř polovina ředitelů (48 \%). Kolem třetiny výběrového vzorku ředitelů krajské sítě žádalo podporu v podobě kontaktní databáze na odborníky, spolupráci s učiteli shodných předmětů a spolupráci s ostatními učiteli dětí/žáků se SVP.

\section{Ř: Zaznamenejte prosím, které $\mathrm{z}$ forem podpory by potřebovali vaši učitelé $v$ oblasti společného vzdělávání?}

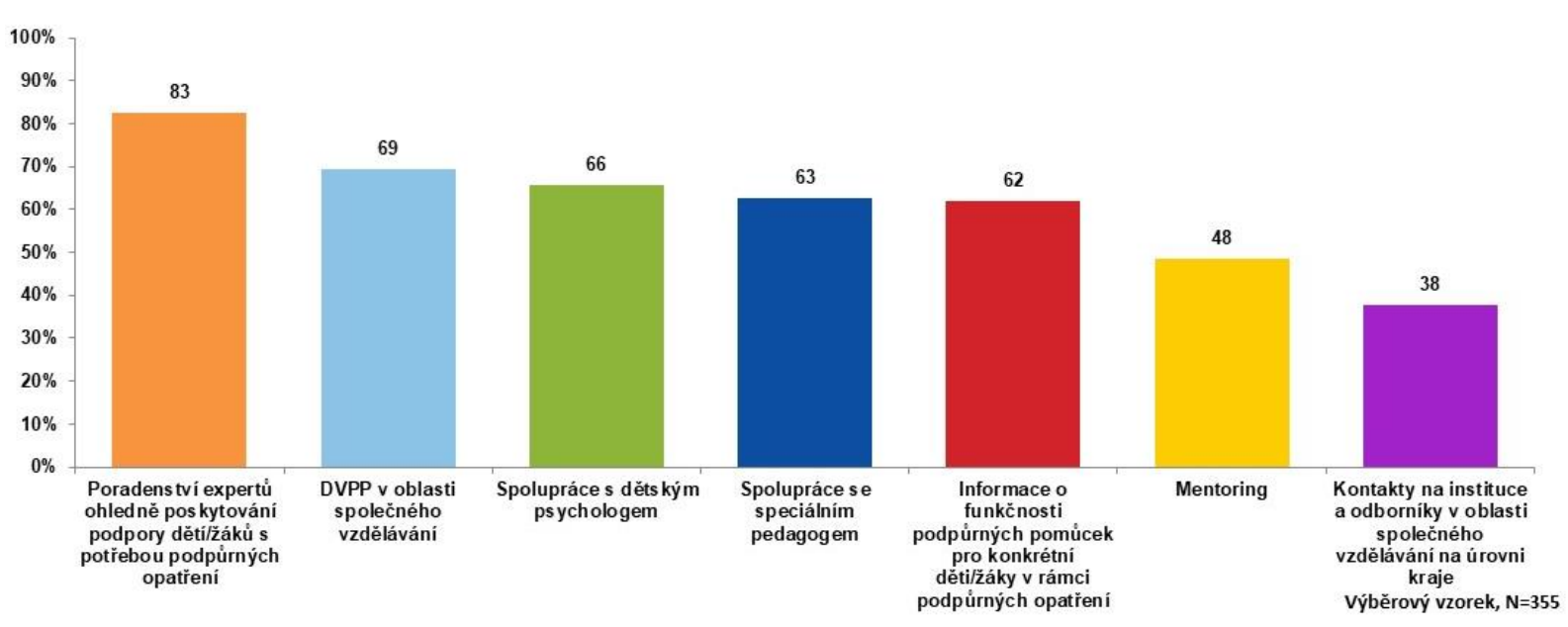

Graf 6 Formy podpory potřebné pro pedagogy v oblasti společného vzdělávání z pohledu ředitelů škol 


\section{Diskuze a závěr}

Z realizovaného vstupního dotazníkového šetření mezi řediteli zapojených škol a školských zařízení $\checkmark$ rámci projektu Podpora společného vzdělávání v pedagogické praxi (APIV B) ředitelé celkově vnímají další vzdělávání svých pedagogů jako dosti významné, ale na datech se ukazuje i jistý posun ve vnímání způsobu podpory společného vzdělávání. S dlouhodobou a stále pokračující podporou inkluze ze strany MŠMT je patrná nejen zvyšující se zralost škol v oblasti společného vzdělávání, ale i nové potřeby škol působících v obtížných podmínkách. Oslovení ředitelé všech typů škol zapojených do krajských sítí zvolili shodně jako prioritní cílenou individuální a specializovanou formu podpory - expertní činnost v oblasti poskytování podpůrných opatření. Další vzdělávání pedagogů se umístilo v pořadí na druhé příčce u mateřských a středních škol, nicméně u základních škol druhé místo obsadila, i když jen s malým rozdílem (+ $2 \%)$, spolupráce s dětským psychologem. Srovnáme-li procentuální zastoupení dalšího vzdělávání pedagogů u jednotlivých typů škol, pak nejvyšší preferenci najdeme u mateřských škol, u nichž lze také najít nadprůměrný zájem oproti jiným typům škol o spolupráci slékařskými profesemi. U základních škol byl zjištěn mírně vyšší zájem o informace o funkčnosti podpůrných pomůcek, dále o mentoring a o spolupráci mezi učiteli shodného předmětu $v$ rámci daného stupně vzdělávání. U středních škol, kde byla podpora škol nejnižší, je patrný průměrný až podprůměrný zájem např́ic všemi kategoriemi odpovědí s výjimkou mírně vyššího zájmu o kontakty na odborníky v oblasti společného vzdělávání a informace $\mathrm{k}$ možnostem zapůjčení pomůcek.

Celkové výsledky u sledovaných témat dalšího vzdělávání poukazují na skutečnost, že jako nejatraktivnější a zároveň nejpotřebnější téma pro učitele zapojených škol se jeví

\section{Cílem studie je popsat} aktuální potřeby ředitelů a pedagogů vybraných škol (MŠ, ZŠ, SŠ) v České republice ve vztahu ke společnému (inkluzivnímu) vzdělávání a také jejich preference výběru témat pro další vzdělávání v této problematice. oblast Sociální interakce mezi učitelem, rodičem a žákem (83\%). Dále následují témata Emoční obrana, zvládání stresu (79 \%) a Pedagogická diagnostika (73\%). Preference a posloupnost témat se sice liší dle typu školy, nicméně uvedená první trojice zůstává víceméně všude stejná. Konkrétně u základních škol se neliší od celkového hodnocení, ale mateřské školy kladly na první místo Pedagogickou diagnostiku a střední školy pak Emoční obranu, zvládání stresu. Nejvýznamnějším diferencujícím faktorem pro nastavení podpory je proto typ školy.

V rámci dosavadní podpory v oblasti společného vzdělávání ředitelé krajské sítě poukazují na fakt, že nejčetnější podporu čerpaly školy v oblasti Legislativy ( $47 \%$ a oproti očekávání toto téma zůstává nadále $v$ popředí zájmu ředitelů i v budoucnosti $(65 \%)$. Důvodem ale již nebude prvotní neznalost spjatá s počátkem novelizace, ale spiše snaha zmenšit míru nejistoty při jejím konkrétním uplatňování v pedagogické praxi. Domníváme se, že tento trend souvisí také se skutečností, že MŠMT legislativu často mění a upravuje, proto ředitelé cítí vyšší a opakovanou potřebu se školit, diskutovat a ujištovat se o možnostech a správnosti uplatňovaných postupů. Administrativa spojená se společným vzděláváním je zatěžující a nepřehledná, ředitelé škol od MŠMT a Národního ústavu pro vzdělávání (NÚV) dostávají často protichůdné informace, což může být další důvod, proč jejich potřeba se vzdělávat trvá i přes vysokou podporu. Náležitosti vyplývající z „inkluzivní vyhlášky“ jsou často nejednoznačně interpretovány a nabízí se také různorodé možnosti pro jejich implementaci v každodenní praxi.

Největší zájem projevili ředitelé o oblast administrativy (75\%), což koresponduje i s dalšími daty z našeho šetření, která indikují její různorodé zvládání (pouze 10 \% ředitelů administrativu zcela zvládá, většina ředitelů ji spíše zvládá). Zajímavé ale je, že podle TALIS 2018 (ČŠl, 2019) se objem administrativní práce navýšil oproti TALIS 2013 v prüměru jen o 12 procent, což je s ohledem na změny, které v mezičase proběhly v souvislosti s inkluzí, a s ohledem na jejich administrativní náročnost méně, 
než by se dalo očekávat. Při bližším zkoumání se $v$ našem šetření ukázalo, že největší problém dělají školám úkony spojené s administrativou obecně a výkaznictvím, tedy více spojené se standardním během školy než $s$ implementací společného vzdělávání. Přibližně třetině škol administrativa společného vzdělávání dál zkomplikovala již tak složité zvládání této oblasti.

Lze také souhlasit s autory publikace Postoje pedagogických pracovníků kvybraným aspektům společného vzdělávání (Michalík a kol., 2018), že inkluzivní edukační trend zastihl české pedagogy nepřipravené na změny, které s novou legislativou souvisely. Jak dále autoři uvádí, základním problémem v nastavení efektivních inkluzivních opatření a přijetí filozofie inkluze je ambivalence pedagogů ke vzdělávání všech žáků intaktních a žáků se speciálními vzdělávacími potřebami v rámci hlavního vzdělávacího proudu, rovněž jejich nedostatečná informovanost a minimum praktické zkušenosti pro práci s žáky s různými vzdělávacími potřebami. Dle zjištění našeho dotazníkového šetření se postupně zájem škol o podporu pedagogů specializuje, individualizuje a přesouvá se směrem ke způsobům nastavení účinné komunikace mezi zapojenými aktéry v rámci společného vzdělávání. Domníváme se, že v řadě českých škol a mezi pedagogy stále chybí potřebná otevřenost, sebevědomí a respekt $\mathrm{k}$ rodičům jako nejdůležitějším partnerům při vzdělávání jejich dětí.

Také volba prioritních témat dalšího vzdělávání v oblasti sociální interakce mezi učitelem, rodičem a žákem potvrzuje již realizovaný výzkum z roku 2013 (Hájková a kol., 2019) v tom, že pedagogové shledávají největší potíže ve spolupráci s rodinou a malou motivovaností žáků, která je ovšem součástí širší problematiky situace rodin $v$ ČR. Svědčí to o tom, že se přiliš nepokročilo $v$ nastavení účinné komunikační strategie pro řešení konfliktních a problémových situací. Tyto závěry do jisté míry potvrdilo i aktuální mezinárodní šetření o vyučování a učení TALIS 2018 (ČŠl, 2019). Z výsledků tohoto šetření vyplývá, že čeští učitelé mají podprůměrné schopnosti v oblasti motivace a aktivního zapojování žáků, jen málo využívají strategie aktivující u žáků náročnější kognitivní procesy (skupinová práce, samostatné řešení problémů, spolupráce apod.) a zároveň ředitelé pocitují nedostatek učitelů s kompetencemi učit žáky se SVP. Tyto závěry svědčí o tom, že v českém školství stále není běžné výuku individualizovat a diferencovat, pracovat efektivně s heterogenní skupinou či podporovat kritické myšlení nebo partnersky komunikovat s žáky či s jejich rodiči. $Z$ toho mǔže plynout i nižší sebevědomí českých pedagogů a podstatně negativnější hodnocení učitelské profese, než je běžné v zemích EU. $90 \%$ českých učitelů je sice v práci spokojeno, ale jen $58 \%$ si myslí, že výhody práce převažují nad nevýhodami (průměr EU činí $71 \%$ ). Pouhých 16 \% učitelů je přesvědčeno, že si společnost váží profese ředitele školy.

Můžeme tedy konstatovat, že zvládání inkluze v českém školství je otázkou celkové schopnosti pedagogů zvládnout nové metody práce, a to prioritně v rámci heterogenního trídního kolektivu, kdy se bude dařit hodnotně vzdělávat jak žáky se SVP, tak i všechny ostatní žáky. Dưvěra v efektivitu tohoto procesu a dobré výsledky všech zároveň usnadní komunikaci o podobě a cílech výuky s rodiči žáků. Inkluze není ukončený proces ani v roce 2019 , má ale už jiné parametry pro nastavení podpory než v roce 2016 a zaslouží si stále vysokou pozornost nejen v oblasti školství, ale i ve spolupracujících oborech. Východisky pro fungující inkluzi v našem školství obecně jsou bezesporu zvýšená metodická, personální i finanční podpora. Předpokladem zvládnutí implementace je ale v neposlední řadě vytváření odpovídajícího stabilního klimatu podněcujícího konstruktivní spolupráci všech zodpovědných pracovníků a institucí, metodická ujasněnost inkluze v ČR, stálá a efektivní osvěta mezi laiky i odborníky a respektování nových potřeb a změn v naší společnosti i ve světě. Novou výzvou je $v$ těchto souvislostech demografický vývoj a křivka stárnutí $v C ̌ R$ spojené $v$ oblasti školství s nedostatkem učitelů, asistentů pedagoga, psychologů, speciálních pedagogů a dalších odborníků. Dlouhodobá, správně cílená a efektivní podpora této oblasti je ze strany státních institucí, představitelů státu, krajů, měst a obcí nezbytná. 
Tento příspěvek vznikl jako součást projektu Podpora společného vzdělávání v pedagogické praxi (APIV B) reg. č. CZ.02.3.61/0.0/0.0/ 16_020/0004015), který je realizován Národním institutem pro další vzdělávání v rámci Evropských strukturálních a investičních fondů Výzvy č. 02_16_020 pro Individuální projekty systémové Operačního programu Výzkum, vývoj a vzdělávání.

\section{Literatura}

Ainscow, M. (2005). Developing inclusive education systems: What are the levers for change? Journal of educational change, 6(2), 109-124. https://doi.org/10.1007/s10833-005-1298-4

Ainscow, M., \& César, M. (2006). Inclusive education ten years after Salamanca: Setting the agenda. European Journal of Psychology of Education, 21(3), 231-238. https://doi.org/10.1007/BF03173412

Ainscow, M., \& Sandill, A. (2010). Developing inclusive education systems: The role of organisational cultures and leadership. International Journal of Inclusive Education, 14(4), 401-416. https://doi.org/10.1080/13603110802504903

Bartoňová, M., \& Vítková, M. (2010). Inkluzivní vzdělávání v podmínkách současné školy. Brno: Masarykova univerzita.

Booth, T., \& Ainscow, M. (Eds.). (1998). From them to us: An international study of inclusion in education. London: Routledge.

ČŠı. (2019, červen 17). Mezinárodní šetření TALIS 2018. Národní zpráva Čšı. Dostupné z https://www.csicr.cz/Csicr/media/Prilohy/PDF_el._publikace/Mezin\%c3\%a1rodn\%c3\%ad\%20 \%c5\%a1et\%c5\%99en\%c3\%ad/Narodni-zprava-z-setreni-TALIS-2018_web.pdf

De Boer, A., Pijl, S. J., \& Minnaert, A. (2011). Regular primary schoolteachers' attitudes towards inclusive education: A review of the literature. International Journal Of Inclusive Education, 15(3), 331-353. https://doi.org/10.1080/13603110903030089

Dopady reformy společného vzdělávání v České republice. (2019, červen 5). Nadace OSF. Dostupné z http://osf.cz/wpcontent/uploads/2017/11/DOPADY_REFORMY_SPOLECNEHO_VZDELAVANI_V_CR.pdf

Hájková, V., \& Strnadová, I. (2010). Inkluzivní vzdělávání. Praha: Grada.

Hájková, V., Pastieriková, L., Klusáčková, M., Daşkın, O., \& Košák, P. (2019, červen 14). Analýza potřeb pedagogických pracovníků $v$ oblasti inkluzivního vzdělávání v projektu Systémová podpora

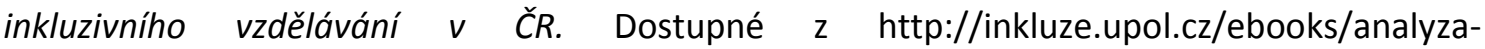
potreb/html5/index.html?\&locale=CSY\&pn=5

Kratochvílová, J. (2019, červen 1). Kvalita inkluzivní školy: Její hodnotová dimenze a podmínky (Habilitační práce). Brno: Masarykova univerzita. Dostupné z https://is.muni.cz/do/rect/habilitace/1441/Kratochvilova/habilitace/Kratochvilova_habilitace_ nahled.pdf

Lechta, V. (Ed.). (2016). Inkluzivní pedagogika. Praha: Portál.

Mareš, J., Průcha, J., \& Walterová, E. (2003). Pedagogický slovník. Praha: Portál.

Michalík, J., Baslerová, P., Růžička, M., Langer, J., Finková, D., Chrastina, J., ... \& Pospíšilová, I. (2018). Postoje pedagogických pracovníků k vybraným aspektům společného vzdělávání. Olomouc: Univerzita Palackého v Olomouci.

Mittler, P. (2012). Working towards inclusive education: Social contexts. London: David Fulton Publishers.

MŠMT. (2019a, červen 2) Akční plán inkluzivního vzdělávání na období 2016-2018. Dostupné z http://www.vzdelavani2020.cz/images_obsah/dokumenty/apiv_2016_2018.pdf. 
Balaban Cakirpaloglu, Odstrčilová, Musilová, \& Bařinková / Společné vzdělávání pohledem ...

MŠMT. (2019b, červen 2) Akční plán inkluzivního vzdělávání na období 2019-2020. Dostupné z http://www.msmt.cz/file/49950_1_1/.

MŠMT. (2019c, červen 2). Dlouhodobý záměr vzdělávání a rozvoje vzdělávací soustavy ČR (2011-2015). Dostupné z http://www.msmt.cz/vzdelavani/skolstvi-v-cr/dlouhodoby-zamer-vzdelavani-arozvoje-vzdelavaci-soustavy-1.

MŠMT. (2019d, červen 1) Strategie vzdělávací politiky České republiky do roku 2020. Dostupné z http://www.msmt.cz/uploads/Strategie_2020_web.pdf

MŠMT. (2019e, červen 1) Dlouhodobý záměr vzdělávání a rozvoje vzdělávací soustavy České republiky na období 2015-2020. Dostupné z http://www.msmt.cz/vzdelavani/skolstvi-v-cr/dlouhodobyzamer-vzdelavani-a-rozvoje-vzdelavaci-soustavy-3.

Průcha, J., Walterová, E., \& Mareš, J. (2003). Pedagogický slovník. Praha: Portál.

Straková, J., Simonová, J., \& Friedlaenderová, H. (2019). Postoje odborné a laické veřejnosti k inkluzivnímu vzdělávání v kontextu obecných postojů k vnější diferenciaci. Studia paedagogica, 24(1), 79-106. https://doi.org/10.5817/SP2019-1-4

Štech, S. (2018). Inkluzivní vzdělávání - obtížné zvládání "rozmanitosti" v praxi. Pedagogická orientace, 28(2), 382-398. https://doi.org/10.5817/PedOr2018-2-382

UNESCO. (2000, leden 5). Dakar framework for action-Education for all: Meeting our collective commitments. Retrieved from https://unesdoc.unesco.org/ark:/48223/pf0000121147

UNESCO. (2019, červen 5) The Salamanca Statement and Framework for action on special needs education: Adopted by the world conference on special needs education. Retrieved from http://www.unesco.org/education/pdf/SALAMA_E.PDF

Vitello, S. J. (1998). The law of inclusion. In S. J. Vitelo \& D. E. Mithaug (Eds.), Inclusive Schooling (pp. 24-39). Mahwah: Lawrence Erlbaum Associates. 